\title{
Organic Coffee Supply Chain Management in the San Martin Region of Peru
}

\author{
Edgar Ramos Palomino, Slee Hilario Meza, Diego Robles Montes, Fernando Sotelo Raffo, and \\ Wei-Shuo Lo
}

\begin{abstract}
The paper is to explore a model of supply chain management organic coffee in San Martin Region, which was by a long-term research project for organic coffee supply chain management in Peru. The investigation was consolidated with items of researchers who have experiences in the evaluation and analysis of the supply chain of agricultural products worldwide; on the other hand, it is also taken into account the risks affecting the development and fluency through whole supply chain. The contributions here is proposed model of supply chain management organic coffee is suitable for exploring external and internal problems encountered decrease the efficiency of the supply chain. The model is important to analyze and require observations of specialists to collaborate to perform basic modeling that can help solve the problems that improving processes and organizations in the coffee farmers' cooperatives in the domestic and foreign market, and achieve recognition for their quality and sustainability in Peru.
\end{abstract}

Index Terms-Organic coffee, organic agriculture, supply chain management (SCM), food, sustainability.

\section{INTRODUCTION}

The research aims to recognize the current operations in the process of supplying the Peruvian organic coffee and look standardize the management of the supply chain level of collection and processing, in order to achieve operational efficiency and strategic effectiveness SCM organic coffee. Research will support the different models recognized supply chain management for the evaluation of the supply chain of organic coffee industry in the northern region of Peru. To explore a proper model of management and utilization of coffee beans that is very important for industrial development, especially, that will be enhancing organic farming technologies and techniques. According to the current situation, organic coffee production in Peru is growing $3.35 \%$ in 2015 [1]. However, various problems are visible in these supply chains. It is observed that is needed in the use of production techniques, load / unload, retrieve / put away, waiting periods, transportation and warehousing that allows to improve production processes. Because, still practices are made empirically.

Then there is low cultural level that restricts

Manuscript received November 17, 2016; revised January 16, 2017.

Edgar Ramos Palomino, Slee Hilario Meza, Diego Robles Montes, Fernando Sotelo Raffo are with the Universidad Peruana de Ciencias Aplicadas, Peru (e-mail: pcineram@upc.edu.pe, u201220402@upc.edu.pe, u201112558@upc.edu.pe, fernando.sotelo@upc.edu.pe).

Wei-Shuo Lo is with the Hospitality Management Department, Meiho University, Taiwan (Corresponding author; tel.: +886-8-779-9821(ext. 8120); e-mail: x2134@meiho.edu.tw). communication of best practices to stakeholders in each supply process, in other words, there is no simple and standardized rules also accepted vocabulary. Therefore, it is necessary to analyze the current structure and processes at each stage of the supply chain to adapt best practices in the process of providing support to manage operations, monitor performance and compliance in an optimal manner. All this will serve to see the impact generated in the current supply chain and business performance in general and associations involved in coffee production. One of the basic concepts that must be addressed is the internal integration within the supply chain, is for several authors, a fundamental part to achieve improvements in logistics processes and evaluate the monetary impact caused in a company. By achieving, establish an internal integration in the links of the supply chain, the responses obtained will be for the benefit of the organization that scope. You can find improvements in quality, delivery, improving flexibility and costs involving all the processes of the supply chain of a product. As mentioned below:

“(...) For example, researchers have associated internal integration with greater efficiency, greater agility in the response of the supply chain, and better quality, delivery, flexibility and cost performance. Of the few studies that assessed the impact of internal integration in the financial, significant and not significant performance relationships found are evident in a positive association of internal integration with the overall performance of the company (an amalgam of sales, profits, and growth indicators)" [2].

Integration applied in the links of the supply chain, generates good results either to interrelate processes to increase profit margins. Some authors mention in their conducted studies that external integration has generated good results because new players are involved in the supply chain such as taking into account and the customer can specify and itemize your basic requirements of a product or service determined:

"Previous research shows that the performance of external integration has a positive impact. External integration had found a positive and direct effect on performance. They found that customer integration was a critical competency that hit the strong overall performance. They found that external collaboration had a positive impact on the performance of logistics. In a related study, it found that formalized collaboration could provide a superior long-term performance. Found that collaboration with suppliers increased financial performance" [3].

The research carried out in the supply chain must have a relational interaction with the various stages of supply management. It is important that theories are understood in 
a simpler way because in the long term are discussed in terms and theories to enrich the process of implementing the supply chain. The research field of the Integration of the supply chain is at home, this means that there will be errors during the execution of a theory or concept in a project. Besides the impact of the relationship between the links of the supply chain can be measured, showing the effects generated to improve or transform operations:

"Fundamental differences in the conceptualization and theoretical linkage of foundational variables suggest that we are failing to provide solid foundations for the discipline. Certainly, we will not fully understand our key concepts overnight. But, we must be concerned that the rush to publish theory-testing work has effectuated a quantitative "arms race," with a primary casualty being the methodical processes of qualitative and conceptual theorization needed to create such foundations. Because SCM researchers are too willing to hurry on to the next theory-testing project before the foundational work is done, the field's credibility suffers. (...) Disarray surrounds the meanings and theoretical identities of behaviors that appear to constitute a continuum of interaction: coordination, cooperation, collaboration and integration" [4].

Also, coordination is a concept that should be analyzed as is done in managing the supply chain in the area of services, it is an experience we can take to find a methodology that allows us to evaluate and analyze a supply chain. On how to study and how processes are linked through the supply chain; further provides coordination between elements with relation to each other at different levels of the supply chain management. As described below:

"Fundamental research in supply chains focuses on the coordination and integration of processes through members of the supply chain. It should be emphasized that the decisions of the supply chain should focus on "what processes should be linked" and what level of integration and management should be applied for each coupling of a process "for research in supply chain on how they should be mapped and modified at appropriate levels of integration "in each link process" [5].

On the other hand, for this investigation we will take the Supply Chain Operations Reference Model (SCOR model) [6] for a structure of the supply chain through 3 levels SCOR helps us to adapt to the supply chain of organic coffee. Delimited our reach from farmer to product delivery to the processing plant, each link has a smaller supply chain internally as suppliers of fertilizers and crop inputs to farmers. The research employed the SCOR model to standardize the supply chain and the ministandar CSCMP [7] to develop metrics and evaluate procedures throughout the scope of the investigation. The combination of these two tools will facilitate the delivery of a management model basic supply chain, evaluating the risks and improving existing processes and / or adding new practices.

\section{SuPPly CHAIN MANAGEMENT - THEORETICAL FRAMEWORK}

\section{A. Concept of Supply Chain}

Traditionally the Supply Chain Management (SCM) is described as the discipline of optimization in delivering goods, services or information linked from supplier to customer. Which consists of different levels, as a supplier, manufacturer, distributor and consumer, but also becomes a network of companies that influence and affect their performance among themselves [8]. SCM best practices in marketing shows various indicators such as demand forecasting, product availability, inventory management and distribution [9]. This leads to the jurisdiction of the supply chain, which in turn is a prerequisite for organizations to react to market uncertainties, finance and maintain its performance.

\section{B. SCOR Model}

The SCOR model is an important guide for organizations to acquire good practices in their processes and analyze the critical points in the links of supply to reduce the progression and flow of informtion between each player in the chain supply.

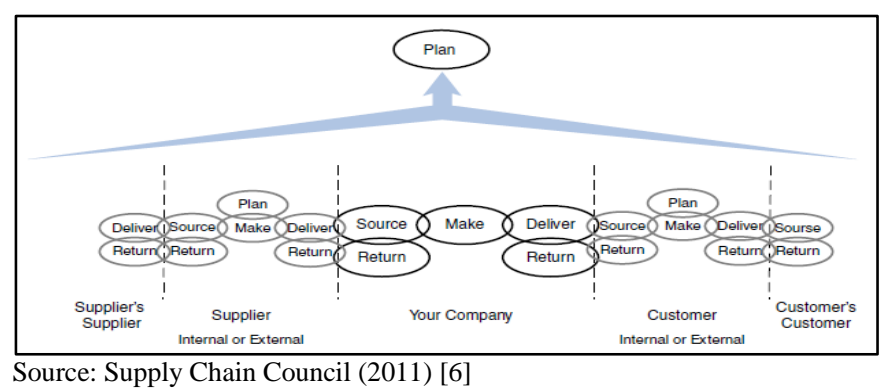

Fig. 1. SCOR model with its five-level strategy processes.

Further, provides a standardized method for describing performance attributes and metrics, configuration, activities, practices and active labor of a supply chain language [10]. Then, the scope of the SCOR model includes all elements of demand satisfaction starting with the demand signal (or planned order) and end with the sign of meeting the demand (final invoice and payment) [11].

\section{Food Supply Chain Management}

As part of the need for standardization, Fig. 2 provides an integrated structure is important in practice to manage operations, monitor performance and analyze compliance and improving the food supply chain (FSC). It also indicates in the center, which is the value chain of products from agricultural land to retailers and different integration areas where products go from one place to another loading / unloading, recovery / disposal, waiting periods and transport: In areas of integration activities as it included [12].

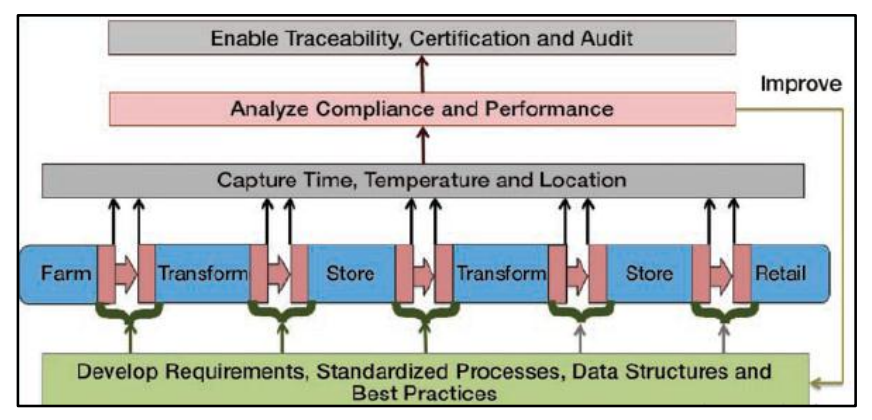

Source: Georgia Tech Integrated Food Chain Center (2012) [12]

Fig. 2. Food integration reference model. 
Management evaluation of FSC has not been given its due attention and should be carried out on the needs / options for reform of policies and regulations that affect farmers' risk management / Agro- business and possible revision / reform of government management instruments risks [13].

An organization to achieve its goals, the structure of FSC involves various stakeholders: farmers, wholesales, collectors, processing or packaging companies, retailers, supermarkets or traditional markets, and customers [14].

\section{A CASE Study - ORGanic CofFEe IN THE SAN MARTIN REGION}

\section{A. Method of Case Study / Data Collect and Analysis}

The coffee sector in Peru was vulnerable after the unfortunate plague that struck the Roya coffee crops in 2013. This led to know the shortcomings that drags the sector for years, such as disorganization, informality, low productivity without offering with consistent quality [15]. On the side of the supply chain, the coffee cooperatives have not standardized coffee production processes, and the means of transport used are very outdated and inadequate, as the use of pack animals (donkeys, mules, etc.) or vehicles that are not in good working order, to carry sacks of coffee beans. In addition, the human overexertion generating physical problems and long-term engines in the local labor is used. Do not pay attention in storing grains because they also lack training treatment of the finished product and its proper handling. Because they adapt their poor facilities for collecting dry coffee bean without considering the environmental variables that give qualities valued by consumers.

This causes the coffee quality does not meet the standards set by international customers, i.e., good quality and homogeneity in each production batch obtained. Consequently, buyers choose to stop buying the product from a particular producer of coffee. It is estimated that agricultural products remain up to $50 \%$ of the time between producers and retailers in the areas of integration products. It is also generally accepted that these areas are the main risk points in the supply chain, many problems can arise in these areas (e.g. misconfiguration load, poor temperature settings, there is no documentation of origin of the product, etc.) that may result in a loss of information, product contamination or degradation in the quality and shelf life. Most of these problems are due to the fact that there are no generally accepted standards or even a standard vocabulary that can be used to communicate best practices to the many partners in the global food chain [12].

\section{B. Current Context of the Coffee Sector in Peru}

In Peru, the coffee beans properly grow from about 600 $2000 \mathrm{~m}$ above sea level, in high valleys and jungle. The average production is 15 quintals of coffee per hectare.

In Peru, the coffee park is 425,000 ha, of which 155,000 ha $(36.5 \%)$ produce specialty coffees certified as organic, reported in 2015 [15]. In addition, there are about 223,000 coffee growers in the country. In addition, the Commission for the Promotion of Peru for Export and Tourism
(PROMPERU) [16] will have 141 coffee export organizations. On the other hand, according to the Peruvian Chamber of Coffee and Cacao (CPCC) [17], Peru is the third largest coffee producer in South America, after Brazil and Colombia. However, in 2015, Peru ranks as the second largest producer and exporter of organic coffee worldwide behind Mexico. According to the ministry of agriculture and irrigation, organic coffee is exported 48 countries: United States, Germany and Belgium mainly.

TABLE I: PERCENTAGE of PRODUCTION By REGION AND DEPARTMENT COFFEE

\begin{tabular}{cl}
\hline Region/Estate & \% Participation \\
\hline Northern Jungle & 65.1 \\
Piura & 1.1 \\
Cajamarca & 21.5 \\
Amazonas & 16.4 \\
San Martin & 26.1 \\
Central Jungle & 20.4 \\
Huanuco & 1.7 \\
Pasco & 2.6 \\
Junin & 15.1 \\
Ucayali & 1.1 \\
Southern Jungle & 14.2 \\
Ayacucho & 1.1 \\
Cusco & 10.8 \\
Puno & 2.3 \\
Others & 0.4 \\
\hline
\end{tabular}

Source: MINAGRI (2015) [1]

As for the harvest of coffee beans in Peru, it has a well-marked seasonality, presented in below:

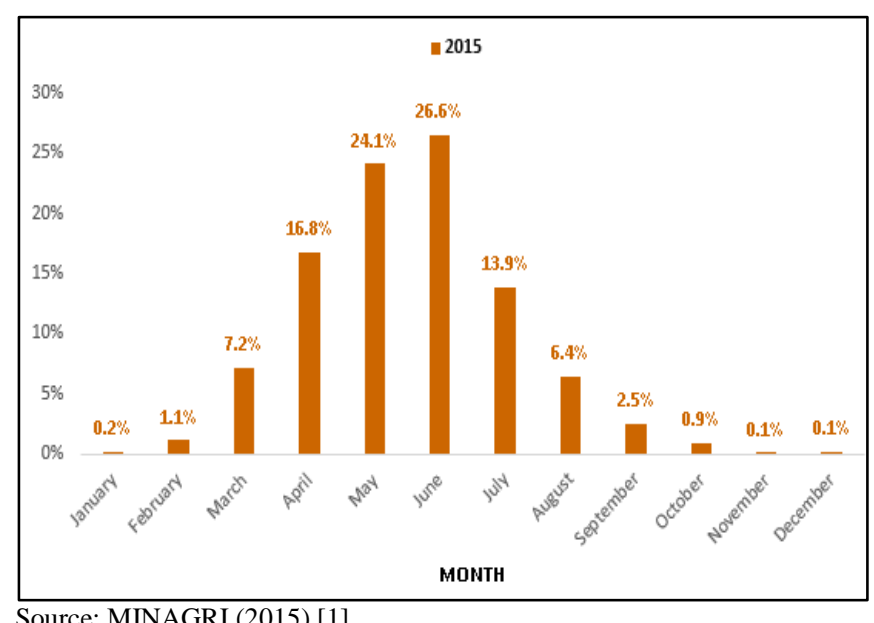

Fig. 3. Seasonality of coffee production in Peru.

From the graph, it is concluded that the bulk of production is concentrated between the months of April and August mainly period in which it is harvested more than $80 \%$ of annual production. By way of example, a cost table is presented between growing coffee versus conventional organic: 
TABLE II: ECONOMIC COMPARISON BETWEEN ORGANIC AND CONVENTIONAL COFFEE

\begin{tabular}{lcc}
\hline \multicolumn{1}{c}{ Description } & $\begin{array}{c}\text { Conventional } \\
\text { coffee }\end{array}$ & $\begin{array}{c}\text { Organic } \\
\text { coffee }\end{array}$ \\
\hline Productivity (qq/ha) & $9 \mathrm{qq} / \mathrm{ha}$ & $15 \mathrm{qq} / \mathrm{ha}$ \\
Plots (ha/producer) & $1.5 \mathrm{ha}$ & $2 \mathrm{ha}$ \\
Sale price (\$ /qq) & $\$ 57.00$ & $\$ 86.00$ \\
Production cost (\$ /qq) & $\$ 33.00$ & $\$ 43.00$ \\
Profit (\$ /qq) & $\$ 24.00$ & $\$ 43.00$ \\
Fair Trade (\$ /qq)* & $\$ 0.00$ & $\$ 20.00$ \\
USDA Organic (\$ /qq)* & $\$ 0.00$ & $\$ 30.00$ \\
\hline
\end{tabular}

* The certification provides a plus prorated among partners

Source: Interview CEO Cooperative CAPEMA [18]

\section{Supply Chain Map of Organic Coffee in San Martin Region}

The mapping performed to coffee cooperatives in the region under study, the main levels of the current situation of the structure of the supply chain was identified; which start from the farmer, continuing collection points, then transforming the parchment gold grain green beans at the processing plant and finally the cooperative manages the entire supply chain of organic coffee for marketing to domestic and international markets.

The main international markets are USA, Germany, Belgium and Japan, which are acquired by the commercial management of the cooperative and trade agreements that Peru integrated. In addition, delivery of the product must have international certifications (Fair Trade, Organic and Rainforest) which guarantee that coffee is organic and sustainable with the environment of the activities involved in the production of coffee.

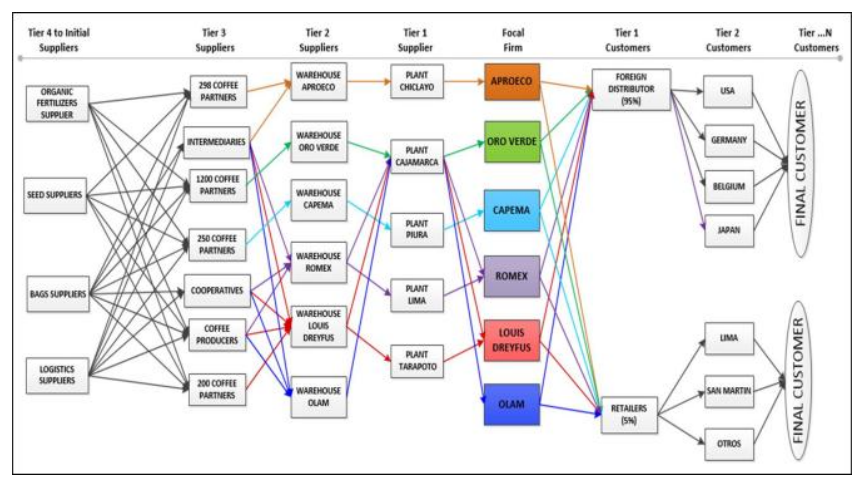

Fig. 4. Supply chain map of organic coffee in San Martin region.

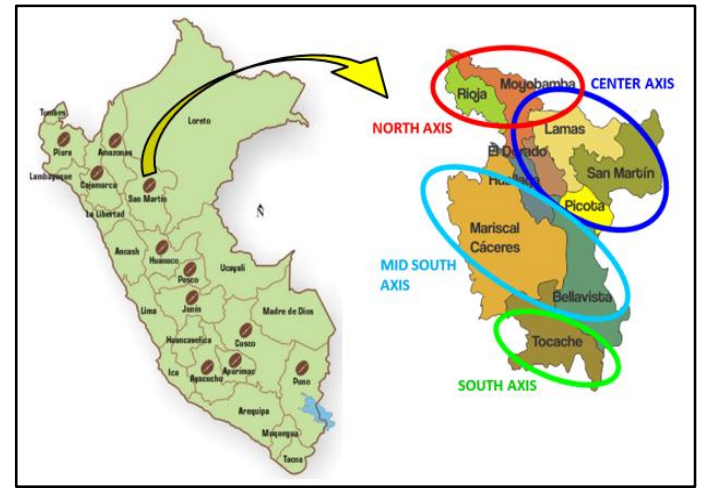

Source: Regional Directorate of Foreign Trade and Tourism (2016) [19].

Fig. 5. Axes of organic coffee production in San Martin - Peru.

\section{Identifying Problems}

Thereafter, an analysis and diagnostic developed in the field of supply chain organizations in producing organic coffee in this region.

Visits and interviews were conducted at the coffee organizations developed in the north and center axes of the San Martin region. This is because more than $80 \%$ of regional productions are given in these axes.

However, there are some factors affecting the ultimate usefulness of producers.

TABLE III: VARIABLES THAT AFFECT THE PRICE OF ORGANIC COFFEE

Performance
Exportable
Reusable or second
Discard or shell
Humidity
Fermentation
Color
Odor
NY Stock Exchange
Exchange rate

Source: Interview CEO Cooperative APROECO [20]

Furthermore, the diagnostic made confirms that the average yield is 15 quintals per hectare. While the use of organic coffee production is distributed as follows:

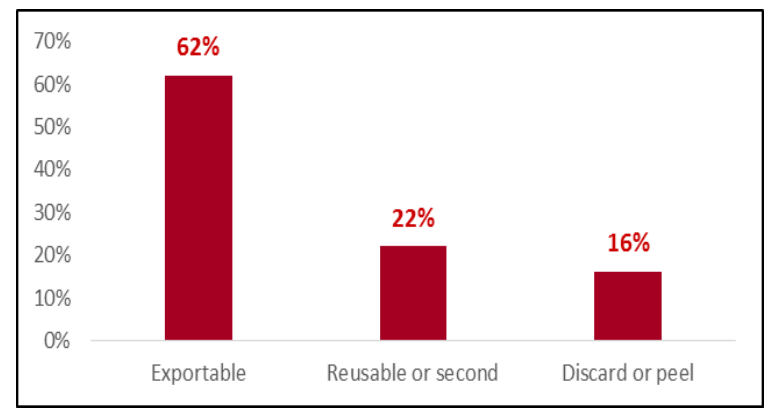

Source: Interview CEO Cooperative ORO VERDE [21]

Fig. 6. Percentage of use on the production of organic coffee.

For its part, the following are observed bad practices by producers:

TABLE IV: POOR STORAge PRACTICES By PRODUCERS

\begin{tabular}{cl}
\hline Process & Description \\
\hline Warehousing & Lack of infrastructure \\
& Disorder \\
& Mishandling of space \\
& Makeshift warehouses \\
& Stacking bags on the road \\
& Predisposition to pollution \\
\hline
\end{tabular}

Source: Interview CEO Cooperative ORO VERDE [21]

Throughout the supply chain of organic coffee different risks are presented in the way.

Small-scale farmers face unpredictable risks as environmental and economic, on such occasions must have or create contingency plans to reduce the consequences of the damage and take practical knowledge of the existence of 
these same. The environment of the productive activity of farmers shown below as an exemplification of the risks and variables both production and delivery of goods.

\begin{tabular}{l} 
TABLE V: PRODUCTION RISKS \\
\hline Drastic weather changes \\
Unstable areas on roads \\
Theft during transport \\
Pests \\
Changes in government \\
Community protests \\
Falling international coffee prices \\
\hline
\end{tabular}

Source: Interview CEO Cooperative APROECO [20]

- Environmental unpredictability and intensifying environmental pressures such as drought and soil nutrient depletion.

- Market volatility.

- Subsidized agricultural imports driving down local prices.

- $\quad$ Food insecurity, malnutrition and food safety concerns. [22]

These factors alter the development and flow of goods along the supply chain as the product varies in quality of origin and traceability (avoid involvement of intermediaries not complying no previous requirements), which it is controlled by the productive associations (cooperatives), to meet the need of the customer (consumer).

Moreover, the communication problems that were perceived presented below:

TABLE VI: COMMUNICATION PROBLEMS IN SUPPLY CHAIN NETWORK

\begin{tabular}{|c|c|}
\hline Personal Issues & Extraneous Issues \\
\hline Heavy workload & Technical problems \\
\hline Frustration & Language \\
\hline Errors & Blame-games \\
\hline $\begin{array}{l}\text { Difficulties with communication } \\
\text { styles }\end{array}$ & Hierarchical issues \\
\hline Lack of information & Natural problems \\
\hline
\end{tabular}

Source: Own elaboration, based on Kewalkrhisna (2014) [23]

Then presented list (with photographs) show the problems that occur along the supply chain.

TABLE VII: REPRESENTATION OF PROBLEMS IN THE SUPPLY CHAIN

Picture
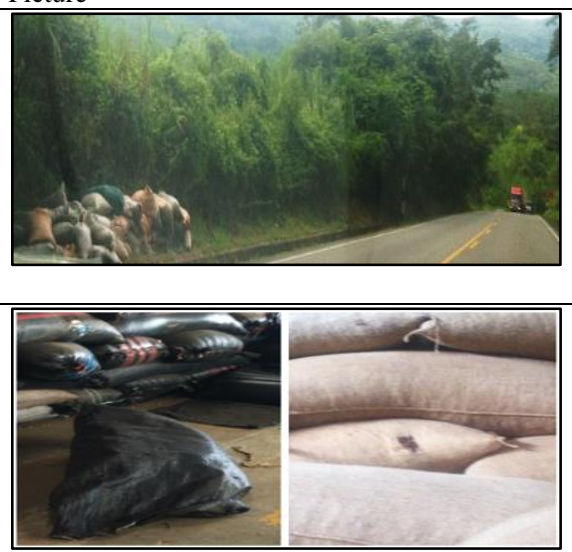

Stacking bags on the road

Description

Problems in the packaging of organic coffee beans

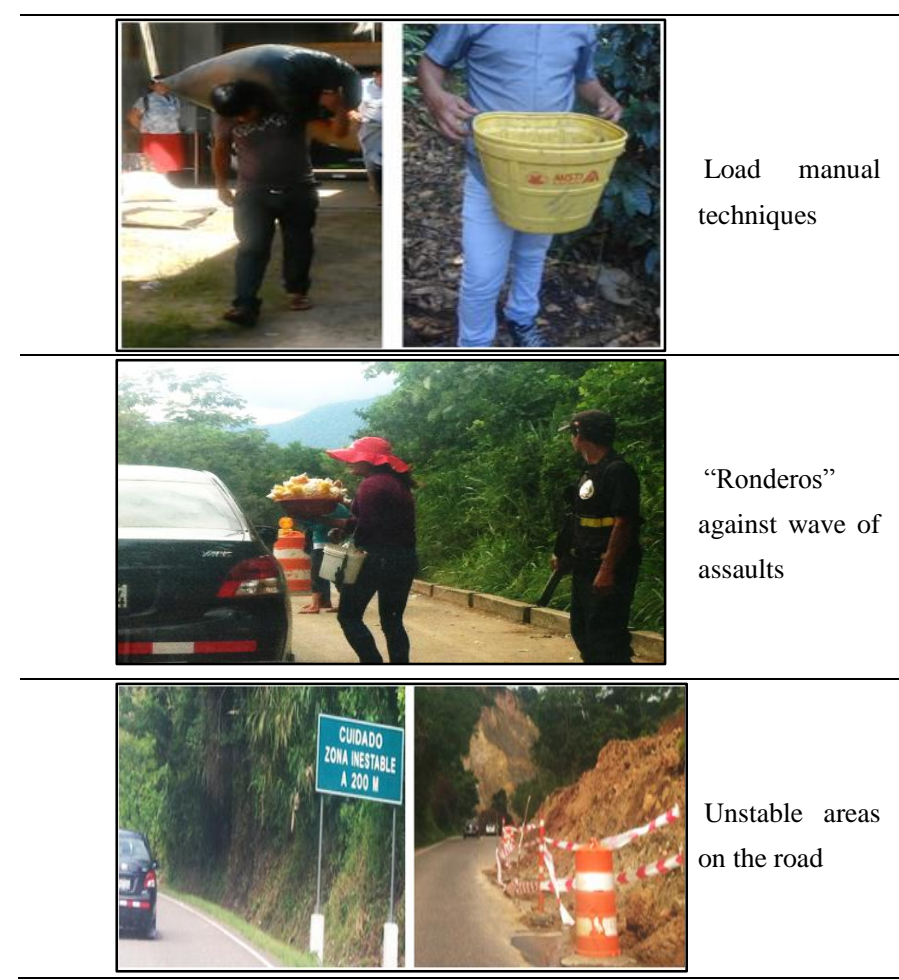

\section{Model Management Supply Chain of ORGaniC COFFEE}

\section{A. Upper Level}

In this study four tiers (farmer, gathering point, processing plant and agrarian cooperative), independently analyzed macro- thus fewer these same be shown by each tier.

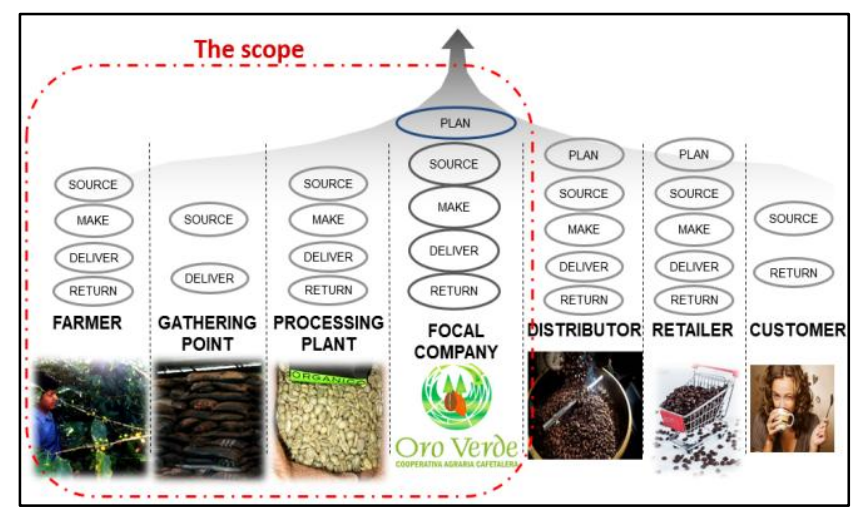

Source: Based on SCOR 10.0 [6]

Fig. 7. Framework of the supply chain of organic coffee.

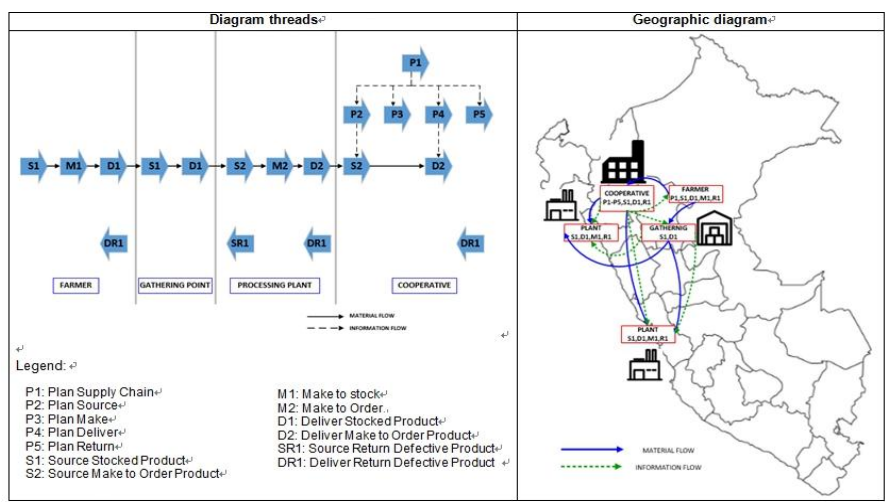

Fig. 8. Process categories. 


\section{B. Configuration Level}

At the next level categories of processes are developed here based trading strategies are implemented to the setting that applies to the particular supply chain.

\section{Level Process Elements}

This level consists of decomposition processes that were previously developed in the configuration level. Companies define styles to successfully compete in the markets, for which some steps are developed:

- Define process elements

- Inputs and outputs of process elements

- Metrics

- Process flow chart

- $\quad$ Procedure sheet

As an example, the development that became a cooperative is presented:

\section{Process Elements in the Cooperative}

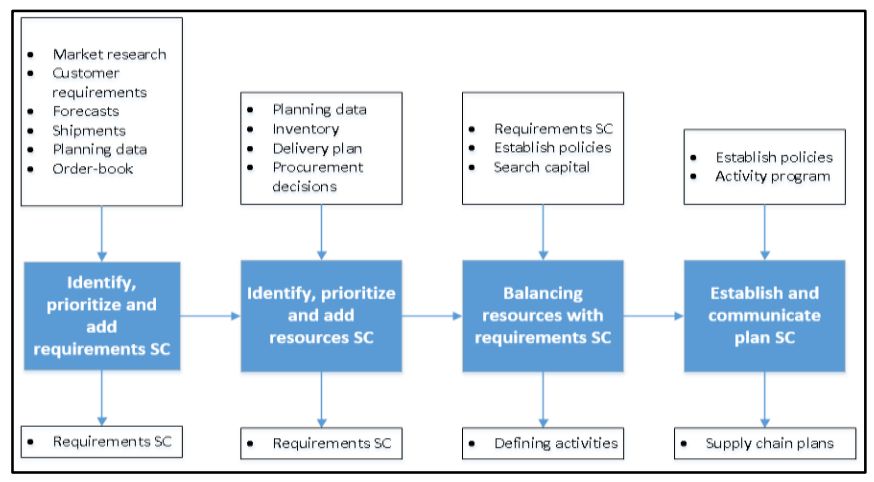

Fig. 9. P1, Plan supply chain.

TABLE VIII: METRICS

\begin{tabular}{llll}
\hline \multicolumn{1}{c}{ Farmer } & Gathering & $\begin{array}{l}\text { Processing } \\
\text { Plant }\end{array}$ & Cooperative \\
\hline $\begin{array}{l}\text { \% Completed } \\
\text { orders }\end{array}$ & \% Provisioning & $\begin{array}{l}\text { Production } \\
\text { capacity used }\end{array}$ & $\begin{array}{l}\text { Cycle time order } \\
\text { fulfillment }\end{array}$ \\
\hline & & Production & \\
$\%$ Provisioning & Inventory cost & cycle time & Cycle time cash \\
\hline Procurement & Finished & & \\
costs & products storage & Production cost & Total cost of SCM \\
\hline
\end{tabular}

Finished

products storage

Source: Own elaboration, based on SCOR Model [6]

\section{E. Sustainability}

Peru belongs to the 12 countries with mega diversity, which represents 60 to $70 \%$ of biological biodiversity (flora and fauna). The agro-economic development of regions alter the socio environmental and natural environment in which are located the hectares of land (plots) to produce agricultural and livestock products; in this case the coffee.

Coffee production in the region San Martin, occurs more quality from $900-1200$ meters (source: farmers and cooperative managers), these growing areas are surrounded by flora and fauna to be transferred habitat for rural communities can develop this economic activity. Currently, there is a focus on the importance of the harmful effects generated by coffee crops. The known as agricultural cooperatives, agricultural organizations conduct training and awareness efforts to mitigate the effects of the natural environment of farming; however, lack of education, technical training and interest of the key players in the coffee production chain perceived as unnecessary preventive measures to be applied permanently in their daily activities.

Sustainability is a concept that has not been included in the management of the supply chain as an important factor to define the operations performed in the links of the same. There have been studies that link the reasons why not often develop research on sustainability in supply management based on behavioral theory and the following are mentioned:

- Skills and abilities;

- Dependence on cooperation with others [24].

According to the theory of behavior, are the aforementioned factors deterring the focus of an investigation of sustainable supply chain in which are presented in most social and environmental aspects.

The economic benefits are obtained through the assessment of sustainability in the supply chain. According to the authors. The authors acknowledge the scope for economic gains in Addition to meeting regulatory compliance [25] identify the benefits associated with this evaluation and how it impacts positively on the economy and the environmental and social environment of chain development productive. In addition they should be used more sophisticated tools to assess sustainability performance and creating effective systems.

This research addresses the origin organic coffee; which must comply with international standards and certifications to be offered to the international market. Organic coffee must be sustainable unlike traditional coffee cultivation; this involves several factors are taken into account in order to make the crops. Sustainability is presented both in culture and in their environment; social, economic, cultural, educational and environmental development is directly linked to the positive or negative consequences of the application of organic coffee farming.

Social development is a consequence of the operations performed consciously with the farmer and a half of development, rural communities in the region still have many basic needs such as sanitation, access to education, means of technological communication (lines and networks telephony), sewer systems, irrigation facilities, access roads transport (road infrastructure), hospital infrastructure, to name some needs that are evident in more urban areas of the region.

Economic development leads to the realization of commercial transactions by agricultural cooperative, which bring together farmers and international markets. The advantage of joining an agricultural cooperative is the perceived economic benefit because prices are transparent and measurable direct farmer participation. Generally farmers who do not belong to these organizations tend to offer their product to the national market and black market (tax-free and food safety, traceability and absence of obtaining crop). The disadvantages are notorious in this system, since there is an unregulated market and only buyers who are outsourced coffee or grain stockers which mostly favor has national destiny. In addition, no 
certification products offered and the low quality is inevitable added when the consumer buys the product. The table shows the economic activities in the region and what is its participation in GDP, analyzed during 2015 is detailed below.

\begin{tabular}{lc}
\multicolumn{2}{c}{ TABLE IV: STRUCTURE ECONOMIC IN SAN MARTIN } \\
\hline Main economic activities in San Martin & \% GDP \\
\hline Farming & $24.3 \%$ \\
Other services & $23.0 \%$ \\
Commerce & $12.7 \%$ \\
Manufacture & $10.5 \%$ \\
Construction & $10.4 \%$ \\
Public administration & $8.7 \%$ \\
Accommodations and restaurants & $3.1 \%$ \\
Transport & $2.9 \%$ \\
Telecommunications & $2.9 \%$ \\
Mining & $0.9 \%$ \\
Electricity, gas and water & $0.6 \%$ \\
Fishing & $0.1 \%$ \\
\hline
\end{tabular}

Source: Ministry of Education of Peru [26].

Cultural development is evidenced increasingly dynamic, currently, companies are have more access to information and by local and foreign tourism can be shared ways of living, culture and 20 other characteristics that make a society different from another. However, access to the media is limited either by the geographical location of the region or the development of infrastructure and technology.

TABLE V: COUNTRY-REGION COMPARISON

\begin{tabular}{ccccccc}
\hline & \multicolumn{6}{c}{ Total visitor/month } \\
\cline { 2 - 7 } Country/Depart \\
\cline { 2 - 7 } ment & Janua & Februa & Marc & & \\
& ry & ry & h & April & May & June \\
\hline \multirow{2}{*}{ Peru } & 304,71 & & 300,3 & 276,0 & 296,1 & 276,7 \\
& 2 & 629,081 & 42 & 86 & 46 & 79 \\
San Martin & 55,507 & 89,334 & 8 & 7 & - & 76 \\
\hline
\end{tabular}

Source: Ministry of Foreign Trade and Tourism of Peru [27]

Educational development is the most important to have greater modernization and improvement of agricultural production in the region pillar. At present, scarce resources by local and central governments for creating public schools, generates disinterest farmers to send their children to school. The lack of education is essential, since only children attending schools at the primary level (1st - 6th grade); because these institutions do not cover secondary education levels (1st -5 th grade). The difficult access and poor infrastructure of public schools are the factors that lead to disinterest attend classes and teachers assigned to the institutions defecting to exercise their teaching work.

The following table shows the investment that has been made in three years comparing the capital of Peru (Lima) with the department of San Martin. Previously, the conditions to be submitted to apply a more accessible education to the people of the provinces of the region under study mentioned; in this case it demonstrated the 3 basic services to be provided by public places such as drinking water, sewerage and electricity.

TABLE VI: INVESTMENT IN EDUCATION

\begin{tabular}{ccc}
\hline \multicolumn{3}{c}{ Public spending on Education as \%GDP } \\
\hline Year & Lima (Capital) & San Martin \\
\hline 2007 & 1.5 & 6.4 \\
2010 & 1.8 & 5.9 \\
2013 & 1.8 & 7.9 \\
\hline
\end{tabular}

Source: Ministry of Education of Peru [26]

TABLE VII: BASIC SERVICES IN LOCAL EDUCATION

\begin{tabular}{ccc}
\hline \multicolumn{3}{c}{ Local public with 3 basic services (\%total) } \\
\hline Year & Lima (Capital) & San Martin \\
\hline 2008 & 87.4 & 20.2 \\
2011 & 86.8 & 28.3 \\
2014 & 91.6 & 33.6 \\
\hline
\end{tabular}

Source: Ministry of Education of Peru [26]

Environmental development is partially regulated by central and local governments, which conducted field visits to verify the information and practices that apply in the pre-production and post-production. The location of the coffee crop, this favored as the surrounding environment; however, water resources are not treated in a responsible way with the environment. Wastes obtained from cultivation are not treated or recycled to reduce the ecological impact; lack of training and lack of farmers aggravate existing local pollution; since the collectors vehicles and synthetic organic residues do not have free access to the place of cultivation of farmers. This represents a high cost to compensate the negative impact on the environment and care that must exist for the importance of the location and surrounding ecosystem growing areas.

\section{CONCLUSIONS}

The main contribution of the proposal for a basic model for managing supply chain for cooperatives producing organic coffee, presented in this article is to develop part of the SCOR model. Then, adapt it to these organizations are in early stages, organizations that have already achieved some results in improving processes and organizations that have implemented the model and are making continuous improvement activities.

In the present paper, the proposal aims to formalize and achieve standardization of supply chain management in the coffee cooperatives of Peru. In this way, it is intended to contribute to the expansion and consolidation of Peruvian coffee in the domestic and foreign market, and achieve recognition for their quality and sustainability.

Implement a model of supply chain management and containing standardized processes established for operational improvement of coffee production generates efficiency and fluidity of operations in the links that make up the production chain of organic coffee.

Technify training processes and provide greater information to reduce the serious consequences on crop fields are enhancement tools that mitigate risks situated at 
each stage of the supply chain.

The required information has been obtained through field visits and personal interviews with the managers of agricultural and peasant proprietors of the agricultural cooperative farms; which was compiled with the statement orally due to lack of records and distrust to provide documents.

\section{REFERENCES}

[1] Ministry of Agriculture and Irrigation (MINAGRI). Synthesis of coffee agro economic. [Online]. Available: http://agroaldia.minag.gob.pe/biblioteca/download/pdf/manuales-bol etines/cafe/CAFE_JUNIO2015.pdf

[2] T. Schoenherr and M. Swink, "The effects of cross-functional integration on profitability, process efficiency, and asset productivity," Journal of Business Logistics, vol. 36, issue 1, pp. 69-87, March 2015.

[3] G. Richey, A. Roath, and J. Whipple, "Exploring a governance theory of supply chain management: Barriers and facilitators to integration," Journal of Business Logistics, vol. 31, issue 1, pp. 240, Spring 2010.

[4] C. Autry, J. Bell, and W. Rose, "Relationship: in search of theoretical consistency and clarity," Journal of Business Logistics, vol. 35 , pp. $275,2014$.

[5] S. E. Sampson, G. Schmidt, J. W. Gardner, and J. V. Orden, "Process coordination within a health care service supply network," Journal of Business Logistics, vol. 36, pp. 355-373, 2015.

[6] Supply Chain Council (SCC), Supply Chain Operations Reference Model (SCOR) Version 10.0 Overview, pp. 6-18, December 2010

[7] Council of Supply Chain Management Professionals (CSCMP), Suggested Minimum Supply Chain Benchmarking Standards, eBook edition, pp. 4-47, 2010.

[8] B. Bigliardi and E. Bottani, "Performance measurement in the food supply chain: A balanced scorecard approach," Facilities, vol. 28, issue 5/6, pp. 249-260, 2010.

[9] G. Kumar and T. Nambirajan, "Supply chain management components, supply chain performance and organizational performance: A critical review and development of conceptual model," International Journal on Global Business Management \& Research, vol. 2, pp. 86-96, August 2013.

[10] K. Rotaru, C. Wilkin, and A. Ceglowski, "Analysis of SCOR's approach to supply chain risk management," International Journal of Operations \& Production Management, vol. 34, pp. 1246-1268, 2014.

[11] H. Cirtita and D. Glaser, "Measuring downstream supply chain performance," Journal of Manufacturing Technology Management, vol. 23, issue 3, pp. 299-314, 2012.

[12] A. Ramudhin and D. Ratliff, "An integrated framework for managing standards and operations of the food industry," Food Logistic, pp. 12, June 2012.

[13] S. Parwez, "Food supply chain management in Indian agriculture: Issues, opportunities and further research," African Journal of Business Management, vol. 14, no. 8, pp. 572-581, July 2014.

[14] W.-S. Lo, "Building agri-food service supply chain managerial framework: A case study in international exhibition," International Journal of Innovation, Management and Technology, vol. 7, no. 2, pp. 72-79, April 2016

[15] National Coffee Board (NCB). Peru, Delegates from 30 cooperatives attend world fair of specialty coffee in USA. [Online]. Available: http://gestion.pe/economia/delegados-30-cooperativas-asisten-feriamundial-cafes-especiales-eeuu-2127992

[16] Peru Promotion Committee for Export and Tourism (PROMPERU). Peru, Official website, It contains information about organizations that export coffee. [Online]. Available: http://www.siicex.gob.pe/siicex/portal5ES.asp?_page_=241.22800\#a nclafecha
[17] Peruvian Chamber of Coffee and Cocoa (CPCC). Peru, the coffee. [Online]. http://www.camcafeperu.com.pe/index.php/elcafe

[18] C. Montalvan, Interview with CEO cooperative CAPEMA, April 30 2016.

[19] Regional Directorate of Foreign Trade and Tourism. Peru, improving the productive chain of coffee and cocoa, by coordinating national and international markets small business organizations in the region San Martin, 2016.

[20] J. Rojas, Interview with CEO cooperative APROECO, April 29, 2016

[21] P. Arzubialde, Interview with CEO cooperative ORO VERDE, April 28, 2016.

[22] H. B. Susan and S. Chelsea, Small-Scale Farmer Innovation, Quaker United Nations Office, Geneva. 2015.

[23] N. Kewalkrishna, "Communication challenges and managing expectations in Indian supply chain and logistics networks: a view from the middle management," Journal of Supply Chain Management Systems, vol. 36, no. 1, pp. 24-39, 2014.

[24] M. Brito and E. Van der Laan, "Supply chain management and sustainability: procrastinating integration in mainstream research," Sustainability, vol. 2, no. 4, pp. 859-870, 2010.

[25] S. L. Golicic and C.D. Smith, "A meta-analysis of environmentally sustainable supply chain management practices and firm performance," Journal of Supply Chain Management, vol. 49, pp 78-95, 2013

[26] Ministry of Education (MINEDU). San Martin, How we in education? [Online]. Available: http://escale.minedu.gob.pe/c/document_library/get_file?uuid=27f7a 01c-4625-4ec4-8986-e9f6ee507e01\&groupId=10156.pdf （accessed on 12. October. 2016).

[27] Ministry of Foreign Trade and Tourism (MINCETUR). Monthly Statistical Report Tourism. [Online]. Available: http://ww2.mincetur.gob.pe/turismo/reportes-estadisticos-de-turismo

Edgar Ramos Palomino is a professor of supply chain management at Industrial Engineering Program of Universidad Peruana de Ciencias Aplicadas, Peru. He is also the team leader and advisor of students' research project for the supply chain of organic coffee. He manages and designs this practical project to be more valuable for organic coffee industry in Peru. Slee Hilario Meza is a student of industry engineering of Universidad Peruana de Ciencias Aplicadas, Peru. His work in this paper is to interview, collect useful articles and propose the basic model of supply chain management.

Diego Robles Montes is a student of industry engineering of Universidad Peruana de Ciencias Aplicadas, Peru. His work in this paper is to interview, collect useful articles and propose the basic model of supply chain management.

Fernando Sotelo Raffo is Director of the Department of Sciences at Universidad Peruana de Ciencias Aplicadas, Peru. He is also the team leader and advisor of students' research project for the supply chain of organic coffee.

Wei-Shuo Lo is an assistant professor at Department of Hospitality Management of Meiho University. He has industrial experiences over 10 years. He also has published many SCM researched articles to international conferences and journals. Especially, he has also had edited books of supply chain management in Chinese. He and Professor Edgar Ramos Palomino are partners of an international cooperation in Agri-food service supply chain in tourism and hospitality industry on Eco-innovation. 